\title{
Kernos
}

Revue internationale et pluridisciplinaire de religion grecque antique

$14 \mid 2001$

Varia

\section{Single-Stemmed Wormwood, Pinecones and Myrrh: Expense and Availability of Recipe Ingredients in the Greek Magical Papyri}

\author{
Lynn R. LiDonnici
}

\section{(2) OpenEdition}

\section{Journals}

\section{Electronic version}

URL: http://journals.openedition.org/kernos/770

DOI: 10.4000/kernos.770

ISSN: 2034-7871

\section{Publisher}

Centre international d'étude de la religion grecque antique

\section{Printed version}

Date of publication: 1 January 2001

Number of pages: 61-91

ISSN: 0776-3824

\section{Electronic reference}

Lynn R. LiDonnici, «Single-Stemmed Wormwood, Pinecones and Myrrh: Expense and Availability of Recipe Ingredients in the Greek Magical Papyri », Kernos [Online], 14 | 2001, Online since 14 April 2011, connection on 30 April 2019. URL : http://journals.openedition.org/kernos/770 ; DOI : 10.4000/ kernos.770 
Kernos, 14 (2001), p. 61-91.

\title{
Single-Stemmed Wormwood, Pinecones and Myrrh: Expense and Availability of Recipe Ingredients in the Greek Magical Papyri
}

\begin{abstract}
Along with prayers, drawings, and strange and powerful divine names, the great handbooks of what is conventionally called "magic" describe and require specific items for the preparation of various recipes that are needed to perform the ritual to the desired result. ${ }^{3}$ Recipes and other ritual instructions generally appear only in these handbooks or formularies, and not in the archaeological traces of spells or rituals actually performed. ${ }^{4}$ But the formularies frequently describe the use of recipes in the ritual creation of
\end{abstract}

1 My research in this area grows out of my participation in two Summer Seminars for College Teachers, sponsored by the National Endowment for the Humanities, and led by John $G$. Gager at Princeton University and by Roger S. Bagnall at Columbia University. I am extremely grateful for the generosity of the $\mathrm{NEH}$ and for the guidance and patience of these two eminent scholars and teachers.

2 The general subject of Greek, Greco-Roman and Greco-Egyptian magic has been investigated intensively in recent years. The indispensible guide to questions arising from the Greek Magical Papyri is W. Brashear, "The Greek Magical Papyri: An Introduction and Survey; Annotated Bibliography (1928-1994)", ANRW II, 18.5 (1995), p. 3380-3684. For surveys that study $P G M$ in the context of the Pharaonic Egyptian tradition overall, see A. Roccati, L. Kákosy, La Magia in Egitto ai Tempi dei Faraoni, Modena, 1985; Y. KoeniG, Magie et magiciens dans l'Égypte ancienne, Paris, 1994. For discussion specifically of Demotic magical papyri, see R.K. Ritner, "Egyptian Magical Practice under the Roman Empire: the Demotic Spells and their Religious Context", ANRW II, 18.5 (1995), p. 333-3379; ID., The Mechanics of Ancient Egyptian Magical Practice, Chicago, 1993 (SAOC, 54). Also see J.G. Gager (ed.), Curse Tablets and Binding Spells from the Ancient World, New York, 1992; D. Frankfurter, Religion in Roman Egypt: Assimilation and Resistance, Princeton, NJ, 1998; Fr. Graf, Magic in the Ancient World (trans. Franklin Philip), Cambridge, MA, 1997.

3 This is not to say that every spell had a recipe; many of them consist only of an invocation to be uttered. But the vast majority do require specific items for their performance, ranging from simple requirements such as papyrus, ink and pen, to the incredibly elaborate initiations of $P G M$ XIII, which require dozens of complicated ingredients.

4 There is a small number of exceptions to this general rule, for example, instructions included on a chariot-restraining defixio, GAGER, Curse Tablets (cit. n, 2), p. 53-56. 
objects of a kind that are in fact found in the archaeological record, ${ }^{5}$ and these objects ("defixiones") may be reasonably thought to have originally been prepared with rituals and recipes not unlike those found in magical formularies.

The formularies or handbooks of $P G M$ contain many examples of spells for sex or competition, but they also contain an even larger number of visionary spells, divination techniques, and prayers for divine assistance and deliverance. The manuscripts themselves derive from Egypt, and were copied or composed between the second and fifth centuries $\mathrm{CE}$, with the greatest concentration of manuscripts in the third and fourth centuries CE. ${ }^{6}$ The Egyptian setting of the manuscripts is reflected in the very large amount of traditional Egyptian material in the spells and recipes, but this is combined with an almost equally large amount of Jewish and Greek material.

The many types of materials called for by the recipes in $P G M$ can, for purposes of study and analysis, be roughly divided into four main types. ${ }^{7}$ These types reflect the function of these materials in contexts outside of $P G M$, and not specific categories in ancient thinking about these substances. They exist to aid the comparison of recipes in $P G M$, with recipes from other sorts of activities in the ancient world. I do not mean to suggest that the ancient formularies themselves reflect any kind of clear typology along these lines - on the contrary, $P G M$ recipes can be dizzying in their multiplication of ingredients, presented in what often appears to be random order. These categories are meant as a typology of comparisons, groups of places and sources from other areas of ancient life where these substances are used or discussed, which may be helpful in determining what kinds of other activities in the ancient world are closest - in technology - to the magical spells, despite how negatively the practitioners of these other activities might feel about the types of activities described by $P G M$.

5 The most dramatic example of a handbook recipe that is apparently linked to five used objects is PGM IV 296-466; full discussion in D.G. Martinez, P.Michigan XVI: A Greek Love Charm from Egypt (P.Mich.757), Atlanta, 1991 (American Studies in Papyro$\log y, 30$ ). In addition to this, there are many amulets and gems that are very similar in type to directions given throughout $P G M$; sources and discussion in Chr. FARAONE, Ancient Greek Love Magic, Cambridge, MA, 1999, p. 11-15, and p. 15 n. 70.

6 An extremely helpful chart of dates and current locations of papyri published in $P G M$ is in H.D. BETz (ed.), The Greek Magical Papyri in Translation, Chicago, 1992 2 , p. xxiii-xxv, which is then updated by a further list of new papyri, xxvii-xxviii, most of which appear in R.W. Daniel, Fr. Maltomini (eds.), Supplementum Magicum 1-2, Opladen, 1990/91 (Papyrologica Coloniensia, XVI.1-2).

7 Many ingredients, of course, are difficult to categorize as belonging exclusively to only one of these categories; there is often a great deal of traffic between them. In fact, the decision to assign a given substance to one or another of these categories will often depend on the overall assumptions one holds about the PGM corpus overall, and so it is important to remember that these categories are for the investigator's convenience and to facilitate the investigation of various methodological issues that appear to cluster around one or another of the "types." 
This having been said, the four basic categories that I notice in PGM recipes are: 1) medicinal plants used in approximately the same way they are used in ancient medicine; ${ }^{8}$ ) consecrated materials, which are prepared and "constructed" for use in a recipe by the rituals associated with their picking or preparation; ${ }^{9}$ 3) materials associated with worship at temple and altar throughout the Mediterranean world and used in $P G M$ in a similar fashion; and 4) unusual, exotic and bizarre materials with no ordinary role in temple life, domestic religion, or medicine, or that are used in ways completely different from their uses in those contexts. While the fourth type is in many ways the most curious, those of the third type, materials associated with temple and shrine, are overwhelmingly the most frequently required. It is with this third category that this paper is concerned.

The materials in question include various kinds of incense, incense burners, lamps, oils, flowers, altars, dishes and cups, fruits, vegetables, and spices. Any of these items was readily available in the marketplaces of even small towns, where they would be required for many different kinds of worship or festivity. There would be no risk of rumor or opprobrium for the purchaser of these items, since they were for the most part staples of religious practice, and indeed of domestic life, just as, e.g., wine or candles are today.

The ease of availability and homely religious overtones of these materials may be contrasted to some of the substances from the other categories: medicinal plants that might be known to be aphrodisiac or poisonous; simple herbs that have undergone elaborate preparatory rituals that are essential but

8 For discussion of these, see J. Scarborough, "The Pharmacology of Sacred Plants, Herbs, and Roots", in Chr. A. Faraone, D. Obbink (eds.), Magika Hiera: Ancient Greek Magic and Religion, New York, 1991, p. 138-174. In this article, Scarborough also briefly discusses categories 2 and 4 . Usage in ancient medicine can still include much that would be considered "magical" by a modern critic, and even ancient authorities were not always in agreement about what was or was not magical about their own - and their adversaries' - pharmacological practice; see P.T. KEYSER, "Science and Magic in Galen's Recipes (Sympathy and Efficacy)", in A. Debru (ed.), Galen on Pbarmacology: Pbilosophy, History and Medicine. Proceedings of the $V^{\text {th }}$ Intemational Galen Colloquium, Lille, 16-18 March 1995, Leiden, 1997 (Studies in Ancient Medicine, 16), p. 175-98; J. STANnARD, "Medicinal Plants and Folk Remedies in Pliny, Historia Naturalis", History and Philosopby of the Life Sciences 4 (1982), p. 3-23.

9 Such substances would not be visibly different from unconsecrated material of the same type; for example, a carefully prepared ring or set of reeds, or plants harvested in particular ways and at specific times. Unless a practitioner made these preparations him or herself, the preparations would have to be taken on trust from the seller of the objects in question. This is a problem not restricted to magical practice, but is an issue in general pharmacology as well, in, for example, Lemnian earth, the pharmaceutical grade of which had to be very carefully prepared; see V. Nutron, "The Drug Trade in Antiquity", Journal of the Royal Society of Medicine 78 (1985), p. 138-145, esp. p. 144; M.-H. MARGANNE, "Les médicaments estampillés dans le Corpus galénique", in DEBRU (ed.), Galen on Pbarmacology (cit. n. 8), p. 19-20. 
not visible to the naked eye; complicated preparations from the bodies of holy animals or murder victims, etc. The ease or difficulty of procuring these items for the performance of a ritual would vary dramatically, depending especially on who you were (priest or farmer, for example), and where you were (in a city or the Upper Egyptian countryside ${ }^{10}$ ). I have argued elsewhere $^{11}$ that in the case of at least some of these, the person desiring to perform a ritual would have had to purchase them from the person he or she consulted for the overall "spell." Such factors make it extremely difficult to use these more unusual substances as any kind of reliable guide to the social or geographical locations our manuscripts presume.

In the case of the incenses, flowers, etc., we are on slightly more stable ground, especially since some of these items were subject to special tariffs, and appear in several economic documents of various dates in the Ptolemaic and Roman eras, ${ }^{12}$ making it possible to estimate both prices and availability of these materials for various periods relevant to the $P G M$ corpus. The reasons for pursuing this question are twofold: 1) determination of the cost to the "end-user" of the performance of certain spells, in the hope of drawing some conclusions about the social and economic level presumed by formularies; and 2) analysis of the degree to which PGM texts are, or are not, characteristically Egyptian and products of the Egyptian priestly class of the Roman period. Do these formularies specifically reflect the religious practices of late antique Egypt, or are they Egyptian examples, preserved due to climatic conditions, of a broader, almost pan-Mediterranean tradition with roots extending back several centuries? Do the surviving formularies represent the eventual collection of diverse small-scale "folk" practices, or the vestiges of working documents of an internally consistent tradition, designed to address the specific social situations faced by its practitioners and the people they served? ${ }^{13}$

10 This point pertains to the question of the point of origin of the Greek magical papyri, whether or not they do in fact derive from Thebes, or even more specifically, from priestly circles within Thebes. Discussion of both sides of this question are surveyed by W.J. Tait, "Theban Magic", in S.P. VleEming (ed.), Hundred-Gated Thebes. Acts of a Colloquium on Thebes and the Theban Area in the Graeco-Roman Period, Leiden, 1995 (P.Lug.Bat., 27), p. 169-182, and also in L. LiDonNICI, "The Disappearing Magician: Literary and Practical Questions About the Greek Magical Papyri", in B.G. WRIGHT (ed.), A Multiform Heritage: Studies on Early Judaism and Cbristianity in Honor of Robert $A$. Kraft, Atlanta, 1999 (Scholars Press Homage Series, 24), p. 227-243.

11 "Beans, Fleawort, and the Blood of a Hamadryas Baboon: Recipe Ingredients in Greco-Roman Magical Materials", in M. Meyer, P. Mirecki (eds.), Ancient Magic and Ritual Power, Vol. II (forthcoming).

12 Not to mention the fact that it is easier to be confident that we know what the substances actually are.

13 For full discussion and analysis of this perspective, see FrankFurTER, Religion in Roman Egypt, cit. n. 2), especially p. 189-264. 
By focusing upon a selected few of these third-category materials, it may be possible to begin to approach these two questions. This paper focuses upon two of the most widely used incenses, frankincense and myrrh, and upon two plant products, pinecones and wormwood, investigating them as test cases, or as a "pilot study" for the overall analysis of $P G M$ materials of all types. These materials are not chosen because they are the four most important, but because they present a range of methodological problems that can affect broader questions of lexicography, pharmacology, economics, social location, and religious practice reflected in the PGM corpus.

\section{Incenses}

The use of incense in temples and in domestic worship is extremely widespread throughout the Mediterranean world and has a very long history. ${ }^{14}$ In the Greek world the use of incense is ancient and pervasive, and may be connected with the etymology of the overall word for sacrifice, $\theta \dot{u} \omega$, which eventually comes to mean sacrifices of all kinds. ${ }^{15}$ In Egypt, incense is attested as early as the Pyramid Texts, and was the goal of a large expedition and transplantation project during the reign of Queen Hatshepsut; ${ }^{16}$ it is also attested from many funerary and domestic-religious sources, and the Egyptian blended incense kufi (kú $\phi \mathrm{l}$ or koí $\phi$ ) was well-known in the Greco-

14 For background and references on the Egyptian, Assyrian, and Israelite uses of incenses, see D. MARTINETZ, K. LoHs, J. JANZEN, Weibrauch und Myrrbe: Kulturgeschichte und wirtschaftliche Bedeutung. Botanik, Chemie, Medezin, Stuttgart, 1988, esp. p. 29-72, 101-151; N. BAum, "SNTR: Une révision", Revue d'Égyptologie 45 (1994), p. 17-39; N. Groom, Frankincense and Myrrb: A Study of the Arabian Incense Trade, London, 1981, esp. p. 137; K. Nielsen, Incense in Ancient Israel, Leiden, 1986, (Vetus Testamentum, Suppl. 38), passim; for the Egyptian uses, A. Lucas, J.R. Harris, Ancient Egyptian Materials and Industries, London, 1962 ${ }^{4}$, esp. p. 80-97; P.T. Nicholson, I. SHAw (eds.), Ancient Egyptian Materials and Technology, Cambridge, 2000; for Greek uses see e.g., S. PRICE, Religions of the Ancient Greeks, Cambridge, 1999, p. 7, 30, 97, 118, 139, 177; W. Burkert, Greek Religion (trans. J. Raffan), Cambridge, MA, 1985, p. 62; M. Detienne, The Gardens of Adonis: Spices in Greek Mytbology (trans. J. Lloyd), Princeton, NJ, 1994, passim.

15 Burkert, Greek Religion, p. 62. Burkert associates the use of incense in Greek sacrifice with the period beginning ca. $700 \mathrm{BCE}$.

16 The expedition was to Punt, but it is not clear whether Somalia or South Arabia is meant. Painted reliefs in the mortuary temple of the Queen at Deir el Bahari depict the trees that were imported as well as large lumps of red incense; Lucas, Materials (cit. n. 14), p. 92-93. The transplantation scheme does not seem to have been effective on any noticeable scale as incense continued to be an imported commodity in Egypt throughout its history; discussion in NiELsEN, Incense (cit. n. 14). Two other helpful resources dealing with trade are N. Grimal, B. MENu (eds.), Le commerce en Égypte ancienne, Le Caire, 1998 (Bibliothèque d'Étude, 121); F. De Romanis, Cassia, Cinnamomo, Ossidiana: Uomini e Merci tra Oceano Indiano e Mediterraneo, Rome, 1996. Under the Ptolemies transplantation was tried again, with similarly disappointing results; S. SIdebotham, Roman Economic Policy in the Erytbra Tbalassa 30 BC-AD 217, Leiden, 1986, p. 10-11. 
Roman period. ${ }^{17}$ Incense was also a required component of sacrifice of several kinds in the Israelite temple in Jerusalem, probably from a very early period and continuing through the destruction of the Second Temple in 70 $\mathrm{CE}{ }^{18}$ Incenses were so important a part of religious life in Rome and the Roman provinces that they were regulated by maximum price limits and state control at certain periods; ${ }^{19}$ and in the first century, Pliny notes that demand for incense (specifically frankincense in this case) was so great that it was beginning to be harvested twice a year. ${ }^{20}$ The use of incenses in so many different religious contexts ${ }^{21}$ and in so many different regions of the Mediterranean world suggests that its use was a very basic component of what ancient Mediterranean people expected a religious act to be like, on the same kind of primary level as fire, oil, animal sacrifice, dressing up, and (except for official Israel) holy images.

This being the case, it is not surprising that many incenses are specified in $P G M$ recipes. ${ }^{22}$ The two most frequently required are frankincense ( $\left.\lambda i \beta a \nu o s\right)$ and myrrh $(\zeta \mu v \rho \nu \alpha)$, and these references increase if we include other incenses that are products or varieties of frankincense and myrh: manna $\left(\mu \alpha v^{\prime} \alpha\right)$ or frankincense powder, and the composite incenses armara

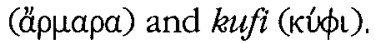

By far, the most frequently required incense in the $P G M$ corpus is $\zeta \mu v \dot{\rho} \nu \alpha$, "myrrh." Myrrh appears so frequently because it is used in the corpus both as an incense for rituals and as a component of black ink for the writing of ritually important words, charaktêres, or pictures. Many recipes call either for writing "with myrrh,"23 using "myrrh ink," ${ }^{24}$ or "myrrhing" a paper, where writing is clearly meant. ${ }^{25}$ Other examples provide recipes for ink in which

17 See discussion of kufi below, p. 78-79.

18 Exhaustive discussion in NiELsen, Incense (cit. n. 14),

19 Sidebotham discusses a possible lost price list used by Pliny as a source, Economic Policy (cit. n. 16), p. 36.

20 Natural History XI, $\mathrm{xxxu}, 58$.

21 Both frankincense and myrrh were also used as medicines; survey in MARTINETz, LOHS, JANZEN, Weibrauch (cit. n. 14), p. 125-151.

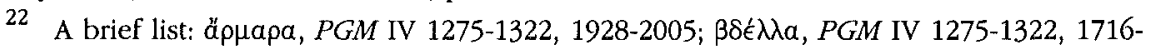

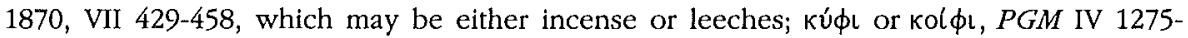

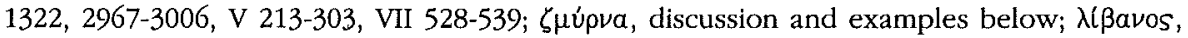

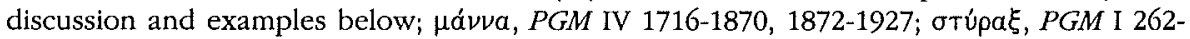
347, III 1-164, IV 1275-1322, 1331-1389 (oil), 1716-1870, 2441-2621, 2622-2707, 2785-2890, VII 429-458, XIII 1-234 (343), 343-646, PDM xiv 309-334, 911-916, 940-952. ővvXa in PGM II 1-64 is clearly the toenail (?) of a ram, but the same word is an incense used in the Jerusalem Temple, Ex. 30, 34.

23 The simple instruction to write $\zeta \mu v \dot{\rho} \nu \eta$, "with myrrh;" there are dozens of examples of this, e.g., PGM I 1-42; IV 850-929; 930-1114, etc.

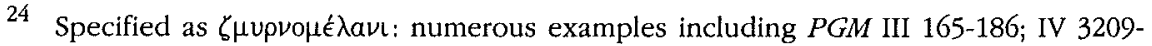
3254; VII 467-477, 505-528, etc.

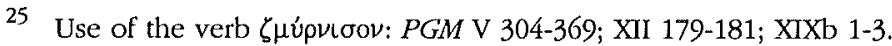


myrrh is an ingredient. ${ }^{26}$ Other incenses occasionally appear in the context of ink, especially in the longer and more elaborate preparations. ${ }^{27}$ The use of incense as the source of soot for the inks of holy books has a long tradition in Egypt and according to one authority, was still standard practice in Coptic Christianity in this century. ${ }^{28}$

When not used as an ink, myrrh appears most frequently in recipes as an "offering" or "sacrifice," 29 burned on an altar or censer, both alone and in combination with other incenses; 17 times in PGM vols. 1 and 2, and PDM. In addition to this, myrrh is used three times in the burial or "funeral" of animals that have lost their lives in the preparation of a recipe, ${ }^{30}$ and twice in the burial of figures or effigies that may represent symbolic funerals. ${ }^{31}$ These are the uses that may be considered part of the third category, materials used in ways similar to their functions in general religious practice. Myrrh also appears in other ways, in examples that should probably be considered in the first or the fourth categories but are included here for completeness and contrast. Myrrh is a component of eye paint prescribed in the Demotic Magical Papyrus ${ }^{32}$ for visionary applications. ${ }^{33}$ Although the "vision" sought by these spells transcends the literal meaning of the word, the medical use of myrrh for the eyes is clear in Dioscorides, where it appears as a remedy for numerous ocular problems. ${ }^{34}$ Myrrh is also used for general favor and luck. ${ }^{35}$ It appears twice in connection with the opening of doors, in two spells that may have some relationship, although this is rather unclear, ${ }^{36}$ and once each

26 PGM I 232-247; II 1-64; VIII 64-110.

27 The subject of $P G M$ ink recipes, which include both carbon and iron based black inks, red inks and one green ink, is a fascinating study in itself, but lies beyond the scope of the present paper.

28 Lucas, Materials (cit. n. 14), p. 363.

29 Ordinarily, various verbs from $\dot{\epsilon} \pi \iota \theta \dot{v} \omega$; nouns from $\dot{\epsilon} \pi \imath \theta v \mu a$; "consecration"

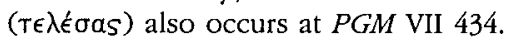

30 PGM IV 475-829; xiv 335-355, 355-365.

31 PGM XIII 321-326; xiv 366-375.

32 The word for myrrh in this document is generally $b^{c} l$, though the word appears in Coptic characters in PDM xiv 376-394, an otherwise Demotic text.

33 PDM xiv 295-308, 805-840, 875-885.

34 Materia Medica I, 64.

35 PDM xiv 115, 309-334.

36 The spells in question are PGM XIII 734-1077 and PGM XXXVI 312-320. The latter is explicitly a recipe for the opening of doors, with the myrrh in combination with the umbilical cord of a firstborn ram being applied to the door bolts while a Coptic invocation is recited; the former is at the very end of the long ms. containing various versions of Moses-related texts, and is an application "for opening doors" in which the "navel of a male crocodile" and other substances are combined with myrrh and simply taken to the door, which is invoked in Greek and with voces magicae. This spell is difficult to analyze, as the animal components are "translated" in the text into various plants, so the extremely unlikely crocodile navel (crocodiles hatch from eggs) is 
as a soaking ointment for a ring, ${ }^{37}$ as a pudenda-poultice that induces sleeptalking, ${ }^{38}$ in a sprinkling water for revelation of a thief, ${ }^{39}$ in a ring to be worn for an erotic purpose, ${ }^{40}$ and in an aphrodisiac lotion. ${ }^{41}$

Unlike myrrh, frankincense ( $\lambda(\beta a v o s)$ does not usually appear as a component of ink, and is almost always a simple sacrifice, ${ }^{42}$ a purificatory sacrifice, ${ }^{43}$ or ritual fumigation. ${ }^{44}$ This use of frankincense appears in approximately 30 places in $P G M$ vols. 1 and 2, and PDM. The few exceptions to this general rule are as follows: (category 4), frankincense as a component of sealing material for a scroll prepared with myrrh ink, ${ }^{45}$ as part of a liquid used on door sockets in an erotic summoning spell, ${ }^{46}$ (category 1), as part of an ointment possibly for a sick foot, ${ }^{47}$ and in an ointment for some problem with the head. ${ }^{48}$

Frankincense and myrrh each derive from the sap of specific trees, ${ }^{49}$ and, like maple syrup, are harvested by making cuts in the bark of the tree at certain seasons, and collecting the juices that run from the cuts. Unlike maple syrup, which must undergo boiling and refinement to render it sweet and usable, the best quality myrrh and frankincense derive from the unadulterated sap, which forms solid lumps when left to accumulate and harden while still running from the tree. Both incenses were available in the marketplace in several different formats and varieties, many of which are

translated as "pondweed." The application does not tell one what is to be done with the recipe, other than simply having it present at the invocation. The relationship between these two texts should be investigated further.

$\begin{array}{ll}37 & P G M \mathrm{~V} \text { 213-303. } \\ 38 & P G M \text { VII 411-416. } \\ \text { 39 } & P G M \mathrm{~V} 172-212 . \\ 40 & P D M \text { xiv 376-394. } \\ { }_{41} & P D M \text { 961-965. }\end{array}$

42 Using the same basic words, verbs from $\dot{\epsilon} \pi \imath \dot{v} \omega$; nouns from $\dot{\epsilon} \pi(\theta v \mu \alpha$,

43 kaقaphós, in PGM V 172-212.

44 PGM II 1-64 (the practitioner's mouth), PGM VII 628-642 (a ring); 740-755 (a tin lamella), 795-845 (a branch), 925-939 (a lead lamella), PDM xiv 117-149 (difficult to determine whether fumigation or the creation of an optical effect with the smoke), and $P G M$ XXXVI 275-283 (a silver lamella - the role of the frankincense is not completely clear).

45 PGM I 1-42.

46 PGM XXXVI 134-160.

47 PDM xiv 1015-1020; the involvement of the foot is suggested only by the fact that the preceding and following recipes concern foot problems, but they do not involve frankincense.

48 PDM lxi 43-48 = PGM LXI i-v.

49 Usually identified as the Boswellia Carteri (frankincense) and the Commiphora pedunculata (myrrh); see Martinetz, Lohs, Janzen, Weibrauch (cit. n. 14), p. 73-100; BAUm, $S N I R$ (cit. n. 14), p. 24-28; Groom, Frankincense and Myrrb (cit. n. 14), p. 96-142. 
named in $P G M$ recipes, although in the majority of cases frankincense is required without modifier. The varieties that do appear reflect grades and provenances, and may be of use in the determination of the relative expense of these ingredients.

Frankincense is discussed in detail in Pliny, ${ }^{50}$ Dioscorides, ${ }^{51}$ and Theophrastus. ${ }^{52}$ While there are divergences among their accounts, these authorities agree that the varieties or grades of frankincense known to them result from the method of collection of the sap from the trees, and to a lesser extent the ages of the trees, mature specimens yielding a more fragrant incense. Both Pliny and Dioscorides describe several grades of frankincense, and for both the highest grade is the a" $\rho \rho \eta v$ or "male" frankincense, for Pliny masculum. This particular grade of frankincense is specified in three $P G M$ recipes. ${ }^{53}$ The designation is unusual here, because there is no corresponding frankincense $\theta \eta \lambda u \kappa o ́ s, ~ " f e m a l e . " 54$ However, in Latin literature of the first century, the term was clearly understood in the gendered sense, and it appears as tus masculum in Pliny's discussion, as well as in Vergil and Ovid. ${ }^{55}$ The term does strike Pliny as strange and in need of clarification, and he attempts a "common-sense" explanation, based upon the roughly spherical shape of some frankincense. But his explanation is undercut by being followed by the remark that the most highly valued frankincense is breastshaped, mammoso, which is apparently a masculum lump that has reached a prodigious size. Pliny continues by saying that Greeks call such lumps, seemingly intending both mammoso and masculum, either stagonian or

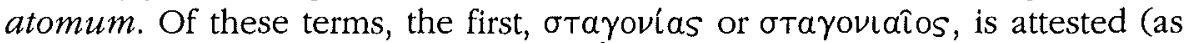
frankincense) both in Dioscorides ${ }^{56}$ and in PGM IV. ${ }^{57}$ The latter term,

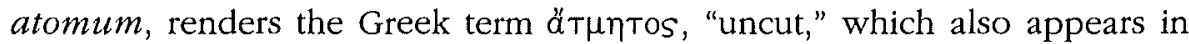

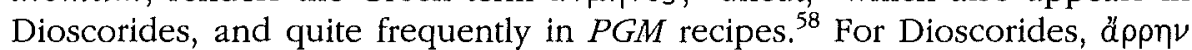

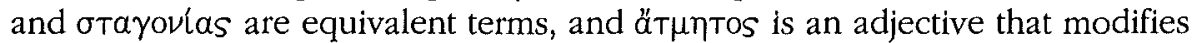
them both; Theophrastus uses $\chi \delta$ ó $\delta \rho \alpha$, a less specific term but by it he appears to mean highest quality frankincense, since it is in connection with the term that he relates the story about the very large size of a natural lump

\footnotetext{
$50 N H \mathrm{XII}, \mathrm{xxx}, 51-\mathrm{xxxII}, 65$.

51 Materia Medica I, 68, 1-8.

52 Inquiry into Plants IX, IV, 1-10, and a brief mention in On Odors, 12-13, 21.

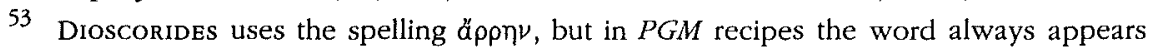

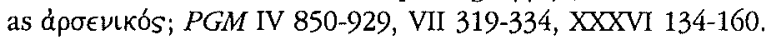

54 Dioscorides uses $d \rho \rho \eta v$ for another plant to be considered in this paper,

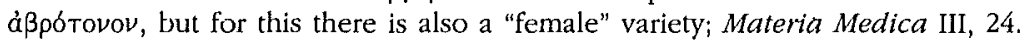

55 VERGIL, Eclogues VIII, 65; OvID, Medicamina Faciel, 94.

56 Materia Medica I, 68, 1.

$57 P G M$ IV 154-285 (215).

58 PGM I 42-195; IV 154-285, 1928-2005, 2441-2621, 2622-2707, 3172-3208; VIII 64-110. The other term for "lump" or "unbroken piece" is $\chi \delta \nu \delta \rho \alpha$, which also appears in $P G M$ II 1-64 and Theorhrastus, Inquiry, IX, IV, 10.
} 
which fills the entire hand, the same anecdote Pliny relates, assigning to the $\chi$ óv8pov the term mammoso. ${ }^{59}$ From these indications it appears that either

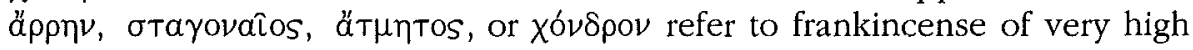
quality.

Pliny discusses three price grades for frankincense, but does not give the names of the varieties in the same place. He does, however, say that smaller lumps or drops are called orobian, and Dioscorides specifically says that the second grade of frankincense is called ópoß $\alpha_{S},{ }^{60}$ which he says is smaller

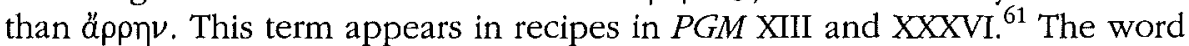
resembles another word, for the plant opoßos, or "vetch." ${ }^{62}$ However, in the first of the two recipes, the term explicitly refers to a bean-sized lump of incense, and it is possible that the second example uses incense as well. ${ }^{63}$ Usage of this term to describe a specific size of pills is widespread in ancient medical literature. But it should be noted that the word does not describe frankincense specifically in PGM XIII, but rather a lump of a blend of seven incenses, including frankincense, for which the recipe had just been given. Pliny's implication is that orobian is a subset within atomos, denoting uncut frankincense lumps of somewhat smaller size, but these references could also be suggesting small lumps broken off of larger ones, or small lumps made out of even smaller lumps, or powder. The identification of the ingredient in these two recipes with the second rank of frankincense is too uncertain to be used.

According to Pliny, frankincense is grown exclusively in Arabia [Felix]. ${ }^{64}$ As noted above, Pliny describes two harvests per year, but continues to regard the summer/autumn gathering as both original and producing a higher quality frankincense, pure and bright white in color. ${ }^{65}$ The winter/spring gathering yields a more reddish sap, though Pliny does not go on to say that the incense itself is consequently reddish. Pliny and Theophrastos agree that frankincense is gathered in two ways, in the droplet form described above,

59 It is not clear whether Pliny uses this passage of Theophrastus as his source, or Theophrastus' own source, or some other source that uses Theophrastus.

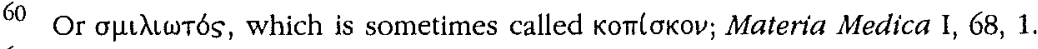

61 PGM XIII 1-234; XXXVI 320-332. For full discussion of the interpretative problems presented by this ingredient, see my article Beans, Fleawort (cit. n. 11).

62 This is the translation choice made by M. SMITH and J. SCARBorough in Betz, GMP, p. 172-173 and p. 277. Scarborovgh discusses his choice in Pbarmacology (cit. n. 8), p. 158.

63 The recipe is preceded and followed by spells clearly involving myrrh, one of the incenses. For spells to appear in handbooks in small groups sharing substances is not uncommon.

$64 N H \mathrm{XII}, \mathrm{xxx}, 51$.

$65 N H \mathrm{XII}, \mathrm{xxxII}, 60$. The whiteness of frankincense is a pervasive characteristic, reflected even in its Greek name, $\lambda(\beta a \nu o s$, a loan-word from the root for "white" in various Semitic languages. 
and by scraping resin that has stuck to the branches or trunk of the tree, causing fragments of bark to be included in the incense. ${ }^{66}$ Pliny goes on to say that this scraped kind is called manna. It is unclear whether this third type of frankincense correlates with the third "grade" which Pliny mentions later. Dioscorides also discusses $\mu$ ávva, describing it as esteemed, white, pure, and granular. ${ }^{67}$ It is required by two adjoining and possibly related recipes in $P G M \mathrm{IV},{ }^{68}$ once as part of a burnt offering and once as a component of a wax figure.

Myrrh is also discussed in detail in Pliny, and to a lesser extent in Theophrastus and Dioscorides. ${ }^{69}$ The latter two authors observe only two varieties of myrrh, lump or droplet form ( $\chi \delta \delta \delta \rho \alpha)$, and a liquid or oil form, stacte $(\sigma \tau \alpha \kappa T \eta ́)$. Pliny discusses stacte and four varieties of solid myrrh, for all of which he gives prices. Of these varieties only one is possibly named by two PGM recipes, myrrh "troglitis" ( $\tau \omega \omega \gamma \lambda \hat{\imath} \tau \iota S \zeta \mu u ́ \rho \nu \alpha) .{ }^{70}$ The term $\tau \rho \omega \gamma \lambda \hat{\imath} \tau \iota s$

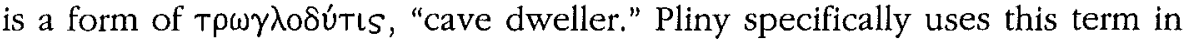
Latin, Trogodyticae, to describe the highest grade of myrrh, which comes not from Arabia like the other kinds, but from the Cave Dwellers' Land, which he says is in the interior of Africa. ${ }^{71}$ Pliny says that Cave-Dweller myrth has the strongest scent, and comes in small pieces that are thick, dry, dusty and "foreign looking," whatever that might mean in this connection. ${ }^{72}$

Pliny says that the price for first-quality frankincense is 6 denarii per pound, for second-quality 5 denarii per pound, and for third-quality 3 denarii per pound. ${ }^{73}$ These and other prices provided by Pliny have been the subject of a great deal of discussion, surveyed by Sidebotham. ${ }^{74}$ The specific nature of these numbers has suggested some kind of maximum price edict for Rome of Pliny's time, otherwise unknown. This if true would support Sidebotham's observation that the use of frankincense in religious and especially funerary ritual made it not a luxury good but a necessity, which it was necessary to insulate from the wide fluctuations in price that can result when a highly desirable item must be imported by sea and caravan. Pliny notes that in his time frankincense was certainly subject to enormous taxes at every stage of

66 NH XII, xxxII, 62; Inquiry, IX, iv, 4.

67 Materia Medica I, 68, 6.

68 PGM IV 1716-1870, 1872-1927.

69 Inquiry IX, IV, 1-10; NH XII, xxxIII, $66-\mathrm{xxxv}, 71 ;$ Materia Medica I, 64-65, spelled бuúpva.

70 PGM I 42-195 (a burnt offering), 232-247 (a component in an ink recipe).

$71 N H \mathrm{~V}, \mathrm{xLV} ; \mathrm{XII}, \mathrm{xxx}, 51$.

$72 N H \mathrm{IX}, \mathrm{xxxv}, 69$.

73 NH XII, $\mathrm{xxxII,} 65$.

74 Sidebotham, Economic Policy (cit. n. 16), esp. p. 34-36. See also Martinetz, Lohs, JANZEN, Weibrauch (cit. n. 14), p. 53-8. For a detailed discussion of the fluctuations of the price of myrrh and other goods, see M. Corbier, "Dévaluations et évolution des prix ( $\mathrm{I}^{\mathrm{er}}$ III $^{\mathrm{e}}$ siècles)", RN série 6, 28 (1985), p. 69-106, esp. 74-75; 80-85; 95-96. 
production and transport, and even if price-protected was still a very valuable commodity, as evidenced by the lengths to which the Alexandrian processing-plant owners had to go to prevent the theft by workers of even the tiniest quantity. ${ }^{75}$

Pliny also reports exact prices for varieties of myrrh: cultivated myrrh being 11, Erythraean/Arabian 16, Cave-Dweller 16,5, and "scented" 12 denarii per pound respectively. Possibly these exact numbers suggest that myrrh, too, was a religious necessity and under some form of maximum price control. Myrrh is certainly requested frequently enough in $P G M$ recipes to suggest that it was both religiously important and readily available. It is interesting to note that the liquid form of myrrh, stacte, does not appear to be under any sort of price control in Pliny's time, as he notes for it an extremely wide price range, from 3 to 50 denarii per pound. Stacte is a component of perfumes, but may be excluded from price protection because it was not then specifically a religious necessity. If so, this might explain why stacte is never requested by $P G M$ recipes. $^{76}$

It is hard to move from the prices listed by Pliny to the Greco-Egyptian marketplace apparently assumed by $P G M$ formularies. ${ }^{77}$ Pliny's date in the $1^{\text {st }}$ century $\mathrm{CE}$ places his valuations, his pound, and his denarius in a completely different economic world than most of the formularies, which are of third or fourth-century $\mathrm{CE}$ date. Also, as Sidebotham notes, Pliny's figures probably describe prices at Rome, ${ }^{78}$ though if they are controlled by edict these prices may be at least analogous to costs of the materials in other Imperial locations.

In the late second century $\mathrm{CE}$, Marcus Aurelius and Commodus published a list of imported items that should be taxed, and in this list we find myrrh being categorized with, among other things, diamonds, Indian eunuchs and panthers; the range of spices, perfumes and precious stones suggest that this is in fact a luxury tax rather than a top price limit on necessities. ${ }^{79}$ Either myrrh has receded in importance, or the reference is to stacte, which as

75 NH XII, xxxII, 59.

76 This may also be reflected in the Portoria Palmyrenorum of $137 \mathrm{CE}$, which established a much higher tariff on myrrh in alabaster containers than for myrrh in goatskin bundles; the only reason to transport myrrh in heavy, fragile, alabaster is if it were in liquid form. This Portoria is discussed in detail in Sidebotham, Economic Policy (cit. n. 16), p. 108-10.

77 This is especially difficult because until Diocletian's economic reforms of 296 , Egypt was on a completely different currency and monetary system; for full discussion, see R.S. BAGNALl, Currency and Inflation in Fourth-Century Egypt, Atlanta, 1985 (BASP, Suppl. 5).

78 Sidebotham, Economic Policy (cit. n. 16), p. 45-46.

79 This list is preserved in Justinian's Digest of Roman Law XXXIX, 4, 16, 6-7, and is reproduced in J. InNes MiLlar, The Spice Trade of the Roman Empire 29 BC-AD 641, Oxford, 1969, p. 279-280. 
noted does not appear to have had a religious role or to have been subjected to price control in Pliny's list. It should be noted that frankincense does not appear in this list and may therefore still be necessary and perhaps protected.

Much later than Pliny's time, and either contemporary or nearly contemporary with the $P G M$ formularies, is Diocletian's Edict of Maximum Prices of $301 \mathrm{CE}^{80}$ In this source, we not only have a clear edict, but also set of regulations that would, for at least a short time and at least in theory, apply to the Empire as a whole. The Edict governs thousands of items, and is organized into categories that are also be useful for determining economic information. For example, in the case of the incenses, at least two fragments appear to label the category in which they appear as pigmentis. ${ }^{81}$ This category includes very diverse items, including both of the incenses under discussion here, as well as absinthe (to be discussed later), many perfumes, medicines, cosmetics, and several varieties of oil; approximately 114 items in all. Crawford and Reynolds suggest that this chapter of the inscription details "items sold by pigmentarii," a merchant class known in Greek as $\mu$ upo-

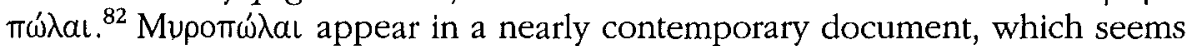
to give market prices for various products at Oxyrhynchus in $329 \mathrm{CE}^{83}$ Although this papyrus lists comparatively few items, many of them also appear in the pigmentis section of Diocletian's Edict. ${ }^{84}$

The Edict gives the price of first-quality frankincense (the only variety listed) at 100 denarii per pound; ${ }^{85}$ and of myrrh troglitis at 400 d.p.p. ${ }^{86}$ Stacte

80 This Edict is known from many inscriptions, both Latin and Greek, set up in diverse locations. Despite numerous witnesses, the text is still fragmentary and parts of it are still unknown. The various witnesses have been collated and edited, most recently by M. Giacchero, Edictum Diocletiani et Collegarum de Pretiis rerim venalium, Genova, 1974.

81 The Aphrodisias copy and the Aezani copy; see M.H. CrawFord, J. ReYNolds, et al., "The Aezani Copy of the Prices Edict", ZPE 34 (1979), p. 163-210; esp. p. 203-204. Giacchero has "plalntis]," Edictum, p. 214.

82 Crawford-Reynolds, p. 204. See also Nutton, The Drug Trade (cit. n. 9); discussion and bibliography in MarganNe, Les médicaments (cit. n. 9).

83 P.Oxy. 2570, III 1-14. See also Corbier, Dévaluations (cit. n. 74), p. 83-84.

84 CrawFord-ReYNolds, p. 204.

$8534,10$.

86 34, 57, as read by CRAwForD-ReYNolds, p. 182. Giacchero has 100 d.p.p. but this appears to be a restoration, p. 216-17. There appear to be three types of myrrh listed; the second two are illegible in the Aezani copy studied by Crawford and Reynolds, but

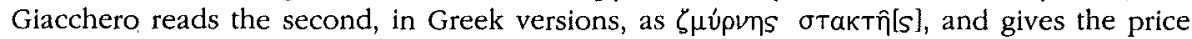
for it as 400 d.p.p; the third kind is illegible both in adjective and in price. Whether or not this second kind is identical with the myrrh-oil, "stacte," is unclear, because there is another entry, clearly бтактทিs, at line 41 in Giacchero's Greek list, with a price of 600 d.p.p.; this name does not appear to be legible in the Aezani version, though a price is preserved in the line, also 600 d.p.p. 
is also listed, at 600 d.p.p. ${ }^{87}$ It is interesting to note that the more widely needed frankincense is controlled at a much more affordable price than troglitic myrrh, or stacte. In the Oxyrhynchus inventory, prices are reckoned differently, and the frankincense, unmodified, is two talents per pound $(\lambda i \tau \rho a)$. This sum, according to Bagnall, should equal 3000 denarii; $^{88}$ but this great leap in price probably reflects fluctuations in gold and related currency, rather than a sharp and sudden rise in the value of frankincense. ${ }^{89}$ Myrrh is listed there as well, but its price is broken away. It is interesting to note that where these three substances can be compared in price, in Pliny and in the $E d i c t$, although the specific numbers vary a great deal, the proportions remain similar, with frankincense at the most affordable level, and troglitic myrrh about four times as much.

How close these figures get us to actual marketplace prices for the individual consumer is very difficult to say, because 1) it is not clear whether these are wholesale or retail prices; and 2) these prices are for the pound, an enormous quantity and much more than is ever requested by a PGM ritual. As noted above, the incenses are most commonly asked for by the lump or grain. Where specific quantities are mentioned, in the composite recipes PGM IV 1275-1322, 1716-1870, and 2441-2621, ${ }^{90}$ the units of measure are the $\delta \rho \alpha \chi \mu$ í and the ov $\gamma k i \alpha$. These requests range from $1 / 2$ to four drachmai, and themselves create a large quantity of incense to be used little by little over a period of time. ${ }^{91}$ In this recipe, 4 drachmas each of frankincense and myrrh are required. Based on the maximum prices in Diocletian's Edict, 4 drachmas of frankincense should cost 6.5 denarii, and 4 drachmas of myrrh (if troglitic)

$87 \cdot 34,41$; see previous note.

88 BAGNALL, Currency and Inflation (cit. n. 77), p. 16-17

89 This is a very complicated issue; for full discussion see BAGNaLl, Currency and Inflation, esp. p. 27-41; ID., Egypt in Late Antiquity, Princeton, 1993, Appendix 2, p. 330-332; Corbier, Dévaluations (cit. n. 74), passim.

90 Repetitions of this last recipe, with variants, appear in PGM IV 2622-2707, 2708-2784, and $2785-2890$.

91 The drachmai mentioned in these recipes reflect units of quantity rather than of currency, but the two ways of measuring are comparable. Ancient pharmacologists use the drachma as a unit of quantity, clearly, since a constantly fluctuating drachma would have disastrous results in the creation of potent medicines. But the medical measurements do follow and reflect the denominations of coinage, for example, 6 obols $=1$ drachma in weight measurement as for coins; figures from J.M. RIDDLE, Dioscorides on Pharmacy and Medicine, Austin, 1985, p. 67-69. For the incense recipes, specific dosages would be less important and the major point would be the proportions of the ingredients; it is therefore not completely impossible that we have here monetary quantities, "a drachma's wortb" of whatever ingredient. But one of the recipes, PGM IV 1275-1322, combines drachmai with ounces, oujkla, which are clearly units of weight and therefore I think that the drachma in these $P G M$ recipes should be taken as a unit of weight. 
should cost 26 denarii, ${ }^{92}$ and these are only two elements of a long recipe. For the sake of comparison, a whole pound of beef is 8 den., a pair of chickens is 60 den., and apricots are 1 den. per pound. Wages are also regulated by the Edict, and range from 25 denarii per day for farm laborers, shepherds, water carriers etc., up through 1000 den. per month for advocates pleading cases. ${ }^{93}$ The relationship between the high and low ends of this wage scale depends upon how many days in a given month the day laborers work and also on the rest of their expenses.

While it may not in fact be possible to approach useful absolute marketplace prices for individual ingredients, it is possible to at least understand their relative valuations, since, even without knowing the specific price, we

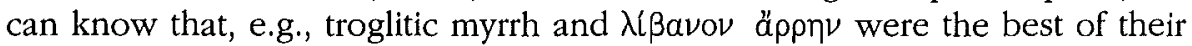
kinds, and whatever their absolute prices, would certainly have been more expensive than other types of the same incense that would also have been easily available. In every case surveyed here, where a $P G M$ recipe specifies a type of myrrh or frankincense, the qualification is toward the more rare and presumably expensive form of the substance. Consideration of other incenses might change this picture somewhat, ${ }^{94}$ but at least for the primary incenses it appears to be so. This is also the case for a broad variety of other substances detailed in $P G M$, where these are described in ancient authors and can be compared. At the same time, large numbers of recipes exist that do not specify particular grades of materials, or that specify simple and inexpensive materials, like bricks. It is not impossible that in this we see simpler and more deluxe rituals for achieving certain ends, that may in fact derive from different levels in the population, that eventually have been collected into the formularies that survive for us. ${ }^{95}$

Further observations about the relative values and/or uses of incenses in $P G M$ recipes can also be made by considering 1) the uses to which each incense is put in the recipe in which it appears; and 2) the explanatory remarks occasionally made by formularies when a given incense is named. From those recipes in which either frankincense or myrrh is set off or distinguished, we see that frankincense is employed more frequently in

92 Using approximate figures that convert drachmas, ounces and the Roman pound into grams. The base figures are from J.W. Humphrey, J.P. Oleson, A.N. Sherwood, Greek and Roman Tecbnology: A Sourcebook, London, 1998, p. xxiv. The authors give a range for the drachma of 4.3-6.3 grams; I have used the average of these figures, 5.3, to calculate 5.15 drachmas to the ounce; and 61.8 drachmas to the pound, based on their figure of 327 grams to the Roman pound.

93 Humphrey, Oleson, Sherwood, Tecbnology, p. 501-505.

94 Pliny, NH XII, LV, 125, says that Cretan storax, called for by PGM IV 2622-2707, is the worst kind.

95 I am deliberately trying to avoid the model of a Prospero-style "magician" with a multipurpose, encyclopedic "magical book" dispensing spells in a variety of price ranges; this is of course also a possibility here, but probably introduces more problems than it clarifies; see discussion in my article, The Disappearing Magician (cit. n. 10). 
oracular or divinatory spells, ${ }^{96}$ in spells for a neutral or beneficent application, ${ }^{97}$ and in rituals that involve the sun, dawn, or Helios. ${ }^{98}$ Myrrh, on the other hand, is used for a wider variety of purposes, for both harmful and beneficent applications. It is possible that the wider employment of myrrh is a reflection of its greater availability; this is based on the descriptions in Pliny, et al., from which it appears that myrrh derives from more locations in Arabia as well as from Cave-Dwellers' Land, and that its harvesters did not need to give a portion of their crop to a god. ${ }^{99}$ On the other hand, Pliny's prices for myrrh are much higher than his prices for frankincense; but since this may be a function of governmental price control rather than market forces it is hard to know what to make of the disparity.

In the few cases where a text expounds upon the nature of ingredients, the claim is made that that frankincense belongs to the solar god/s, while myrrh belongs to Selene. The most concrete example is in the recipe

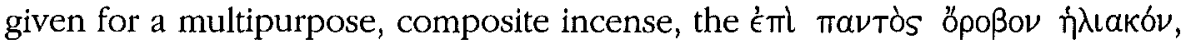
"solar incense-lump for every occasion," detailed at the beginning of PGM XIII. ${ }^{100}$ While the compounded incense itself is referred to as "solar," in describing each ingredient the author clearly states that frankincense is the proper incense of Helios, and myrrh that of Selene, citing at least two other authorities for these correspondences. ${ }^{101}$ In another case involving an initiation that takes more than 24 hours to perform, frankincense is sacrificed at dawn, and then myrrh at evening. ${ }^{102}$ At a much later date, Paul of Aegina records two recipes, a "Great $K u f i$ " which he calls $i \lambda \iota a k o ́ v$, and then

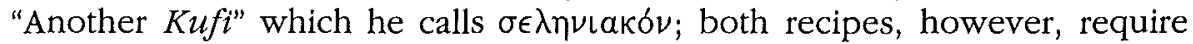
myrrh and share the majority of ingredients, though they appear in different order. ${ }^{103}$ Plutarch claims that in temples, at least, myrrh is burned at midday, and the composite incense $\kappa \hat{\nu} \phi \mathrm{L}$ is burned at sunset. ${ }^{104}$ Pliny does state that the frankincense harvesters had to pay a portion of their harvest to "the god

96 PGM I 1-42, 42-195; II 1-64; IV 154-285, 850-929, 3172-3208; V 370-446; VII 319-334, 540-578, 628-642, 740-755, 795-845; XIII 1-234, 343-646, 734-1077; "xiv" 117-149, 395-427, 856875, 875-885; I.XXVII 1-24.

97 All of the examples of frankincense (outside of its usage in blended composite incenses) are beneficent, except three: PGM IV 850-929, 2441-2621; XXXVI 134-160.

98 PGM I 1-42, 42-195; II 1-64; IV 154-285, 850-929, 1275-1322, 1928-2005; V 172-212, 370446 (indirectly); "xiv" 117-149, 856-875, 875-885.

99 NH XII, xxxiII, 63, 68.

100 The recipe is at lines 14-24, and is repeated with less detail at lines 353-354. For opoßos as a lump rather than a bean, see above, p. 70.

101 He cites a work called The Key of Moses, parts of which may appear later in the codex at lines 213-343, discussion in The Disappearing Magician (cit. n. 10). He also claims that the correspondences are "in Manetho's book."

102 PGM I 42-195.

103 Paul of Aegina, Seven Books VII, 22, 4-5.

104 Plutarch, Isis and Osiris, 372d, 383c, 384c. 
they call Sabis." It is not clear from Pliny's account what kind of god this is, ${ }^{105}$ but from Theophrastus' account he appears to be a solar god. ${ }^{106}$ Later, in his enumeration of prices and grades, Pliny mentions a third-grade type of myrrh called "Dianite."

Whether or not it has any specific connection to Selene, the use of myrrh is explained in several $P G M$ recipes in terms of its bitterness. Incenses in general are described as bitter, astringent and heating in pharmacological literature, but in $P G M$ it is specifically the bitterness of myrrh that is stressed. Two erotic recipes, possibly related, are directed not to any god but to the myrrh itself, which (probably through its meandering smoke ${ }^{107}$ ) becomes the power that is invoked and sent to draw the female victim of the spell: ${ }^{108}$

You are Myrrh, the bitter, the difficult, who reconciles combatants, who sears and who forces to love those who do not acknowledge Eros. Everyone calls you Myrrh, but I call you Flesh-eater and Inflamer of the heart... ${ }^{109}$

Elsewhere, a recipe for restraint requests a fumigation in ápw $\mu a \sigma \iota v$ qaıis

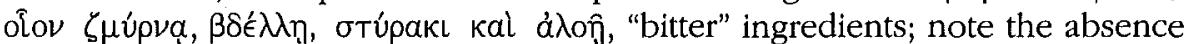
of frankincense which is usually described as "sweet," despite its medicinal uses. ${ }^{110}$

There is little, apart from these traces, to account for the choice when one particular incense is spotlighted and used in isolation. I think that the most important overall point about the use of incenses is that they are used as purifiers, purgers, and to attract, honor, and propitiate divine powers functions that do not differ greatly from their use in temples and in funerary and domestic worship. When incenses are used in combination, as in the "bean" recipe in PGM XIII, these functions are extended and addressed to a range of divine powers.

For the first question that this paper investigates, we have seen that, although absolute prices are difficult to determine, where recipes specify varieties of incense, they usually require the finest varieties which, based on Pliny's relative prices and Diocletian's Edict, would appear to be the most expensive. This is borne out by other materials not surveyed here, such as

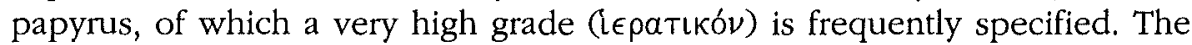
second question, about the extent to which $P G M$ texts reflect the extension

105 Other than a national one, the people under discussion being called Sabaei; $\mathrm{NH}$ XII, $x x x, 51-52$.

106 However, Theophrastus, Inquiry IX, 4, 5-6, says that both frankincense and myrrh which Pliny specifically denies - are gathered into this temple for distribution and sale.

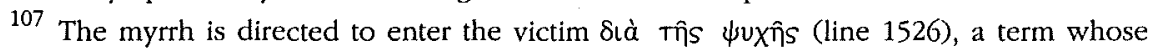
connection with breath is well-known.

108 PGM IV 1496-1595; XXXVI 333-360.

109 Trans. E.N. O'Neil, in Betz, GMP ${ }^{2}$, p. 67.

${ }^{110}$ PGM VII 429-458. 
or transformation of indigenous Egyptian priestly traditions, requires further discussion of the Egyptian blended incense, kú $\phi \mathrm{l}$, a very famous substance in antiquity and requested by four PGM recipes. ${ }^{111}$

Among the several Pharaonic terms for incense is the term $k 3 p . t$, which appears quite early and continues to be mentioned throughout Egyptian literature. It appears that in early periods this term referred simply to any blend of incenses. ${ }^{112}$ In Ptolemaic times, however, two hieroglyphic inscriptions from Edfu and one from Philae $^{113}$ recorded specific recipes for this blend. In the following centuries, recipes for kufi also appear in Dioscorides, ${ }^{114}$ Plutarch, ${ }^{15}$ Galen, ${ }^{116}$ and Paul of Aegina. ${ }^{117}$ These recipes require a great many ingredients, ten in Dioscorides, sixteen in Plutarch and Galen, approximately sixteen in the Ptolemaic inscriptions, and a maximum of 32 in Paul of Aegina. There is great variation in the specifics of these recipes, ${ }^{118}$ but certain key shared elements appear consistently: raisins and/or dates, wine, flowers, but especially imported spices and resinous incenses, specifically myrrh and bdellion, and probably frankincense as well. ${ }^{119}$ While much remains to be determined about these recipes, for the question at hand it should be noted that the numerical majority of named ingredients are the same valuable, imported resinous incenses that we have already been discussing. In other words, there do not appear to be any ingredients in kufi

111 PGM IV 1275-1322, 2967-3006; V 213-303; VII 528-539.

112 Nielsen, Incense, p. 12; V. LoRET, "Le Kyphi, Parfum sacré des anciens Égyptiens", Joumal Asiatique 1887 (July-August), p. 81-87. The term appears in this sense in Papyrus Ebers of ca. $1534 \mathrm{BCE}$; no specific recipe is given, contra RIDDLE, Dioscorides on Pbarmacy and Medicine (cit. n. 91), p. 90.

113 LORET, Le Kyphi, p. 86-95. The recipes in these inscriptions are also discussed in J. DümICHEN, "Ein Salbölrecept aus dem Laboratorium des Edfutempels", Zeitschrift für Ägyptische Sprache und Altertumskunde 17 (1879), p. 97-128. A more recent philological analysis of the inscriptions is Ph. Derchain, "La Recette du Kyphi", Revue d'Égyptologie 28 (1976), p. 61-65.

114 Materia Medica 1.25; see also M.-H. MARGAnNe, "Les références à l'Égypte dans la Matière Médicale de Dioscoride", Serta Leodiensia Secunda. Mélanges publiés par les Classiques de Liège à l'occasion du $175^{\circ}$ anniversaire de l'Université, Liège, 1992, p. 30922, esp. p. 313.

115 Plutarch, Isis and Osiris, 383e.

116 GaLEN, De Antidotis II, 2.

117 Paul of Aegina, Seven Books VII, 22, 4-5.

118 For detailed discussion of all except Paul of Aegina, see Loret, $K y p h i$ (cit. n. 112), p. 76-132.

119 The specific identification of ingredients in these Ptolemaic hieroglyphic recipes is difficult. According to L. Manniche, An Ancient Egyptian Herbal, Austin, 1989, p. 57-58, both frankincense and myrrh are clearly named in all three of them. The Greek recipes request a kind of $\dot{\eta} \tau(\nu \eta$, probably from a terebinth tree; full discussion in LORET, $L e$ Kyphi (cit. n. 112), p. 128-130; BAUM, SNTR (cit. n. 14), p. 24, disputes Loret's identification of sntr with resin, and argues that it is frankincense. 
that can only be obtained in Egypt, ${ }^{120}$ at least at the date of the Ptolemaic inscriptions or seven centuries later in $P G M$ formularies. Moreover, the fact that recipes for it are so widely published in both Plutarch and technical literature may indicate that 1) large numbers of people knew about kufi and wanted to know what it contained, and 2) anyone literate in Greek and near a major marketplace could make his own kufi at any time. Therefore, the presence of kufi in a recipe is not in itself a diagnostic element that brands a text as "priestly-Egyptian." Moreover, the widespread use, attested in Dioscorides, ${ }^{121}$ of kufi both as a medicine and as a perfume further suggests that it was a widely available substance, likely to be found in well-to-do homes. ${ }^{122}$

\section{Pinecones}

Several $P G M$ recipes request $\sigma \tau \rho \circ \beta\left(\lambda \circ{ }^{123}\right.$ generally interpreted as "pinecones." 124 Of these recipes, one uses the $\sigma \tau p o \beta i \lambda$ ol in a recipe for ink, ${ }^{125}$ and one uses them ground up in an aphrodisiac drink. ${ }^{126}$ The remaining

${ }^{120}$ Plutarch, however, does stress the fact that the kufi is prepared in temples "while

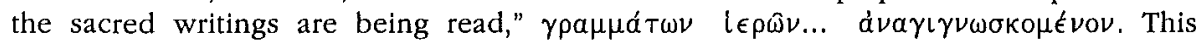
requirement is present only in Plutarch and if observed, would move kufi into my category 2, consecrated materials.

${ }_{121}$ Materia Medica I, 25.

122 Before leaving the incenses, there is one other blend, ä $\rho \mu a \rho a$, referred to as a "sacrifice" and known only from two spells in PGM IV: 1275-1322 (1294), which gives a recipe (1308-1315), and 1928-2005 (1999). From the recipe this is also a typical blend of wine, herbs, and imported spices and resins, which itself calls for kufi as an ingredient (as well as the brain of a black ram).

123 Or $\sigma \tau \rho \circ \beta i \lambda \iota a$, a diminutive form, PGM I 232-247; VII 167-186.

124 One occurrence of the word apparently describes a component of a bath-house

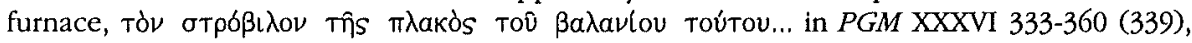
which is the second of the two invocations to Myrrh discussed above. The parallel

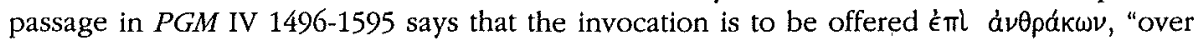
coals," and nothing in the text that follows appears to assume a bath-house. There does not appear to be any reasonable way to construct this reference into an actual pinecone,

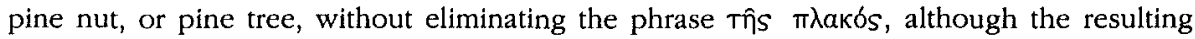
term is not otherwise attested as a component of a bath. In any case, the phrase clearly describes the place of the performance of the ritual, rather than a recipe ingredient in the usual sense, and so I am not including it in my counts or my overall discussion.

125 PGM I 232-247.

${ }^{126}$ In the so-called "Table Tricks," PGM VII 167-186. The oтpoßi $\lambda \iota a$ here may actually be pine nuts. The term does appear in medical writing; it is noted for its usefulness against coughs and chest problems, in Soranus, Gynecology I, 123 (in a cough drop for children), and in Dioscorides, Materia Medica I, 69 (pitch from kwval mixed with honey and used for coughs and diseases of the chest), and V, 35 ( $\sigma \tau \rho \circ \beta(\lambda\llcorner\alpha$ soaked in sweet wine as a drink good for consumptives). Diocletian's Edict lists "pure pine nuts"

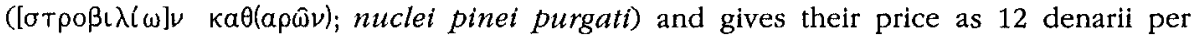


seven examples ${ }^{127}$ use pinecones as part of elaborate sacrificial preparations, in every case in visionary and oracular spells. Each one of them uses the pinecone in combination with a dozen or more ingredients and elaborate ritual preparations, sometimes of several days' duration. Pinecones never appear by themselves in simple preparations, but form part of the texture of an extremely rich religious experience.

Like the incenses described above, pinecones were used widely throughout the ancient Mediterranean and Near East, in a broad variety of religious, funerary, and honorific contexts. In Greece itself, the use of pinecones at least in Dionysiac worship is attested in art from a very early time; ${ }^{128}$ in Asia they are also significant in the religion of Attis. ${ }^{129}$ They appear in Egypt as offerings to Osiris. ${ }^{130}$ In the Ptolemaic period, one of the Zenon papyri describes $\sigma т p o \beta(\lambda$ ol as "useful to the king." 131 A category of merchant,

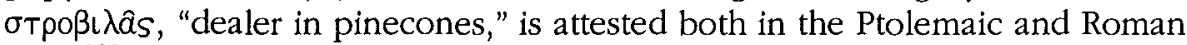
eras. ${ }^{132}$ Although pinecones are not as rare and exotic as some of the incenses, the existence of this merchant category may suggest that they are still either imported goods or cultivated produce in Egypt. Therefore, the request for pinecones in a $P G M$ recipe should not suggest a practitioner going out and obtaining them directly from the countryside; ${ }^{133}$ like frankincense and myrrh, pinecones are to be found in marketplaces.

To this day, people will include pinecones in wood fires for the additional fragrance they impart to the smoke. It is likely that several of the $P G M$ references do describe a similar use, where they are grouped with incenses and instructions for fire; ${ }^{134}$ the grouping of pinecones with other aromatics is also frequent in the papyri surveyed by Chapa. ${ }^{135}$ But in two recipes it is unclear whether the pinecones are actually burnt or just sitting as part of the furnishings of an offering table that includes fruits, cakes, and sweets

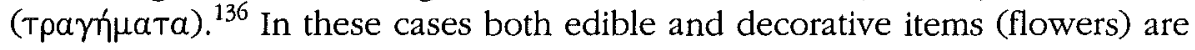

Italian sextarius. These pine nuts appear in a long list of greengrocer's stocks, GiAcCHERo, Edictum Diocletiani (cit. n. 80), p. 148-149.

127 PGM II 1-64, 64-184; III 633-731; XII 14-95; XIII 1-234, 343-646, 734-1077.

128 But the earlier word for the pinecone is kwvos.

129 As noted by J. ChapA, who has provided an extremely useful overview of the religious uses of the pinecone in Letters of Condolence in Greek Papyri, Florence, 1998 (Papyrologica Florentina, XXIX), p. 70-71.

130 Chapa, p. 71.

131 The reference is to the planting of trees; P.Cair.Zen. II, 59157, 1.4-5, v. 7; CHAPA, Letters of Condolence (cit. n. 129), p. 70.

132 P.Oxy. XII 1446, 58; CPR XIII 29, 75; CHAPA, Letters of Condolence (cit. n. 129), p. 70.

133 See also discussion of the letter of Tasoucharion, below.

134 PGM II 1-64, probably 64-184; probably III 633-731; probably XIII 1-234, certainly 343-646.

135 CHAPA, Letters of Condolence (cit. n. 129), p. 70.

136 PGM XII 14-95; XIII 734-1077. 
requested, and so while it is possible that the $\sigma \tau \rho \circ \beta(\lambda \circ \mathrm{o}$ in question are pine nuts rather than pine cones, either choice is possible and there is no real reason to choose one over another. Chapa notes that in addition to these two references, a list of items used in a ritual for the Dioscuri also requests pinecones and тparńnata "in close association." 137 They are also closely associated in the letter of condolence from Tasoucharion to her brother Neilos, which is Chapa's main focus. ${ }^{138}$

The letter of Tasoucharion is part of an archive of five letters, all from (if not physically written by) Tasoucharion to her brother Neilos. ${ }^{139}$ The letter of condolence is written on the occasion of the death of Neilos' wife Taonnophris. Tasoucharion is unable to attend the funeral but has sent a

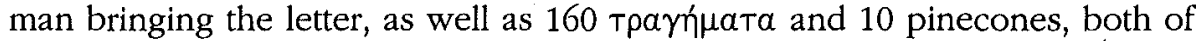

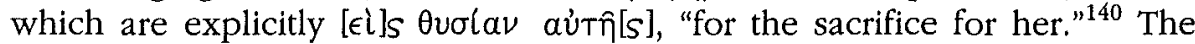
letters were all found in the Arsinoite nome, and in them Tasoucharion speaks of going "up" or "upriver" to her brother's home; her frequent mentions of the Serapium suggest that her own home is in or near Alexandria. ${ }^{141}$ The letters concern a variety of business deals, some on an impressive scale ${ }^{142}$ indicating at least a relatively well-off family. These letters suggest two points about pinecones: 1) it may be easier to get them in Alexandria than in the Arsinoite, as Tasoucharion sends them "up," a reinforcement of the suggestion above that pinecones were purchased in marketplaces rather than gathered on country rambles; and 2) ten pinecones is an appropriate number to send, from a comfortable or well-off sister to a close brother on an important family occasion. This latter point is of interest for the $P G M$ recipes, since the quantity is analogous to the amounts most of the recipes request: seven, ${ }^{143}$ ten, ${ }^{144}$ and twelve ${ }^{145}$ are the numbers specified,

137 P.Lund IV 11, 13; 24; CHAPA, Letters of Condolence (cit. n. 129), p. 71.

138 BGU III 801; CHAPA, p. 65-72.

139 The archive: $B G U 2,601 ; 2,602 ; 3,714 ; 3,801$; P. Giss. 97; СнAPA, Letters of Condolence (cit. n. 129), p. 65-66.

140 Translation, Women's Letters from Ancient Egypt, 300 BC-AD 800, by R.S. BAGNALL, R. Cribiore, with contributions from E. Ahtaridis (to appear in the American Council of Learned Societies History E-book series; paper version forthcoming).

141 Bagnall-Cribiore, Women's Letters From Ancient Egypt; $\mathrm{C}_{\mathrm{HAPA}}$, Letters of Condolence (cit. n. 129), p. 66 (at least for the letter of condolence).

142 BAgnall-Cribiore note that the 4 minas mentioned in $B G U 2.602$ "was more than a legionary's annual salary," Women's Letters From Ancient Egypt.

143 PGM I 232-247; XII 14-95

144 PGM XIII 1-234. The second "version", at lines 343-646, halves the number of both pinecones and roosters, but may assume the original sacrifice and add to it.

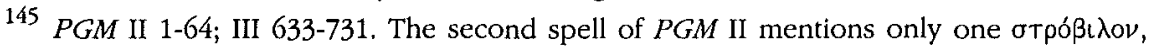
but may be adding this to the sacrifice of the original twelve. 
and this appears to be roughly the quantity needed for a ritual. ${ }^{146}$ These numbers are enough to impart a nice fragrance to the sacrificial fire, but are not enough to have been themselves the fire's only fuel.

In $P G M$ recipes, a peculiar adjective is sometimes applied to pinecones: ${ }^{147}$ $\delta \epsilon \xi$ lós, translated in the Betz collection as both "whorled to the right," "full of seed." 149 The adjective itself is not peculiar, being employed in dozens of places in PGM, but always in the sense of "on the right" or "the righthand" lung, eye, shoulder, sandal, etc. - in other words, of things that come in pairs of left and right. The word can also mean "excellent" or "perfect," but it does not appear with this sense anywhere in PGM; and so the translation choice "whorled to the right" is in fact most consistent with the use of the term in other $P G M$ contexts. Outside of $P G M$, the word has a wide range of meanings beyond the right-hand direction, including "skillful," "northerly," and "courteous." 150 These terms do not seem any more appropriate in connection to pinecones. Another meaning, "fortunate or lucky," like "excellent" probably assumes or derives from attitudes about the right hand or side, and may make more sense when applied to pinecones, resulting in "lucky pinecones" that are not necessarily made so by being "whorled to the right," but perhaps by the tree from which they come, their mode of gathering, or time of gathering. From another perspective, if we look at these four recipes, we see that in all four cases the pinecones are closely associated with the sacrifice of a white, unblemished rooster (or more than one). The unblemished nature of the rooster is expressed by several different words, but because in all four cases this quality of the rooster has $\sigma \tau \rho \circ \beta i \lambda$ o $\delta \in \xi$ to lurking about in the same phrase, it seems possible that it is in this category of meaning that one should search for the definition of $\delta \epsilon \xi$ เol, and so therefore the suggestion of "perfect," "fortunate" (because perfect), "the right kind" ("right" because unblemished, English colloquial use also working along the lines of prejudice toward the right over the left sides) is probably to be preferred to the more consistent "whorled to the right."151

146 The large number of $50 \sigma \tau \rho \circ \beta(\lambda \iota \alpha$ required by the aphrodisiac drink in PGM VII 167-186 is another reason to suggest pine nuts rather than pinecones (however tiny) for the meaning there.

147 In four instances, PGM II 1-64; III 633-731; XIII 1-234, 343-646.

148 J. Dillon and E.N. O'NEIL for PGM II 1-64, noting an alternative possible translation "perfect in shape," BETZ, GMP, p. 13, n. 9; M. MEYer for PGM III 633-731 notes the possibility as well; BETZ, GMP, p. $35 \mathrm{n}, 140$.

${ }^{149}$ M. SMITH for PGM XIII 1-343 (9) and 343-646 (368); in the first instance Smith notes that this was apparently Preisendanz's choice, and also notes the alternative meaning "with spirals running to the right," BETZ, GMP, p. 172, n. 4.

${ }^{150}$. LSJ, s.v.

151 Preisendanz does translate the term as "full of seed" at PGM XIII 9 and 368, as M. Smith mentions, but at II 25 and III 694 he opts for "right-oriented." There is no discussion in Preisendanz of either choice. 
For the questions under investigation here, the use of pinecones in $P G M$ reinforces the observations made about incenses. They are not easily gathered in the countryside of Egypt, but rather are to be found in major marketplaces, such as Alexandria, where they are bought by Tasoucharion to

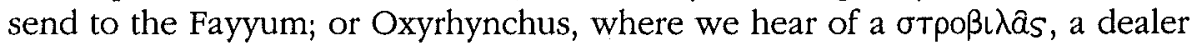
in pinecones, in the $2^{\text {nd }}-3^{\text {rd }}$ century $C E .{ }^{152}$ While the pinecones do not appear to have been quite as rare or as expensive as some of the incenses, they remain a commodity with value - one must part with goods or money to obtain them; and the relatively small quantity of ten comprises a good gift in Tasoucharion's letter. The only qualifier associated with pinecones, $\delta \epsilon \xi \xi_{\text {lós }}$, may specify an even more high-end article, an unblemished or perfect pinecone, and it should be noted that in the four recipes in which $\sigma \mathrm{T \rho} \rho \beta$ i $\lambda$ ol $\delta \epsilon \xi$ Lo l are required, they are combined with dozens of other items in a ritual recipe that must have been very expensive to perform, simply by the sheer number of required substances, many of them imported. Although an extremely poor rural inhabitant would have neither easy access to a market, nor disposable income to purchase pinecones, I do not doubt that they would make a great effort to provide whatever was needed for a family funeral. But once again we see that ingredients in these recipes, in this case visionary recipes, ${ }^{153}$ appear to exclude any but those with, literally, "money to burn."

\section{Wormwood}

A discussion of "wormwood" either does or does not belong in the present study, which is meant to be concerned with $P G M$ substances that also play roles in temple and domestic worship. My uncertainty here comes from the fact that there are many varieties of "wormwood," in antiquity as well as today, and although some of these are used in temple and possibly domestic worship, others, including the specific variety required in $P G M$, are apparently not. However, ancient writers on these plants constantly introduce synonyms for these terms, ${ }^{154}$ and these synonyms sometimes relate to each other just enough to cause one to wonder whether or not these

152 It is not clear from these examples whether pinecones are exclusively imported from out of the country; but even if they could grow in Egypt, they would have been rare and "imported" inside the country from wherever they were available. LuCAs, Materials (cit. n. 14), p. 319-22, speaks of pine products in general as imports from Asia and Arabia.

153 In other words, not recipes for farming or business success. Of course, where the goal is to open a relationship with a powerful deity, there is no telling what will occur in the conversation that takes place "when he comes."

154 For all questions relating to names, identifications, and synonyms for ancient plants, an essential resource is J. André, Les noms de plantes dans la Rome antique, Paris, 1985. 
terms sometimes were meant to refer to the same plants, or whether or not these different but related plants were simply interchangeable in recipes. ${ }^{155}$

In the category of "herbs," no plant is more frequently required in $P G M$ recipes than $\dot{\rho} \rho \tau \epsilon \mu \iota \sigma l \alpha$, with 21 requests for various types and parts of the plant. It is used eight times as a component of ink, ${ }^{156}$ six times it is just present in various formats in the furnishing of the ritual or offering table, ${ }^{157}$ three times it is burned or "sacrificed," 158 and once it is made into a paste to be rubbed onto pure lips. ${ }^{159}$ It also appears twice in the problematic "Priestly Interpretations" list. ${ }^{160}$ The plant is requested both without modifier and also

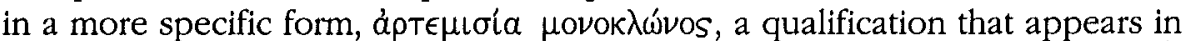
10 out of the 21 occurrences of the term. ${ }^{161}$ Both Pliny ${ }^{162}$ and Dioscorides ${ }^{163}$ discuss various kinds of artemisia and their uses, in terms similar enough to suggest a common source, ${ }^{164}$ but this source is not Theophrastus, who does not discuss a plant called "artemisia."

"Wormwood" is the translation of this term that appears in LSJ, and this was the choice made by the editors and translators of the Betz translation.

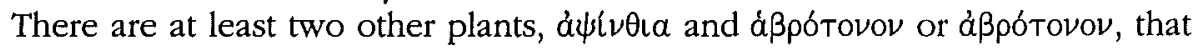
are also defined as "wormwood" by LSJ. All three of these, each with several varieties, are discussed by Pliny and Dioscorides, and are considered separate

155 For a similar approach to a different substance, see P. Galllard-Seux, "Le 'sang de basilic' chez Pline l'Ancien (N.H. XXIX, 66) : résine de genévrier ou hématite ?”, $A C 68$ (1999), p. 227-238.

156 PGM I 232-47; II 1-64; IV 2145-2240, 3172-3208; VII 222-249, 993-1009; VII 64-110; XII 96-106.

157 Held in right hand, $P G M$ III 733-731; in a crown, IV 850-929; woven into a mat, IV 930-1114; in a wax figure, V 370-446; seeds arranged around a lamp, VII 593-619; its root inscribed and held, XII 397-400.

158 PGM IV 1275-1322, 2622-2707, 2891-2942.

159 PGM II 1-64. In the broken foreknowledge spell III 282-409, a $\rho T \epsilon \mu$ if $\alpha$ is mentioned, but its use cannot be determined.

160 PGM XII 401-44; the broken text III 282-409 may also be a kind of synonym list that includes the term. For discussion, see LiDonnicr, Beans, Fleawort (cit. n. 11); GaILLARDSeux, Le 'sang de basilic' (cit. n. 155), p. 228-229; 233-236.

161 PGM II 232-247; III 282-409, 633-731; IV 930-1114, 2145-2240, 2622-2707, 3172-3208; VII 222-249; VIII 64-110; XII 96-106.

162 PliNy mentions the plant in various recipes throughout, but the main discussion is Natural History XXV, xxxvi, 73-74.

163 Materia Medica III, 113.

164 For full discussion of the problem of the sources of these authors, see RIDDLE, Dioscorides (cit. n. 91), p. 14-19. For Pliny's sources in particular, see M.-H. MARGANNE, "L'Égypte médicale de Pline l'Ancien", Centre Jean-Palerne. Mémoires X. Le Latin médical: La constitution d'un langage scientifique, Saint-Étienne, 1991, p. 155-171; J. Scarborough, "Pharmacy in Pliny's Natural History: Some Observations on Substances and Sources", in R. French, Fr. Greenaway (eds.), Science in the Early Roman Empire: Pliny the Elder, bis Sources and Influence, Totowa, NJ, 1986, p. 59-85. 
entities by them. Theophrastus discusses varieties of $\dot{\alpha} \psi \dot{\iota} \nu \theta \iota \alpha$ and $\dot{\alpha} \beta \rho \operatorname{tov}^{\prime} \nu \nu$ only, but also distinguishes between them. ${ }^{165}$ The only reasons to investigate $\dot{\alpha} \psi(\nu \theta \iota \alpha$ and $\dot{\alpha} \beta \rho o ́ t o \nu o \nu$ in a discussion of $\dot{\alpha} \rho \tau \epsilon \mu \iota \sigma / \alpha$ in $P G M$ recipes are indirect: 1) two interesting but convoluted trails of synonyms that may indicate that some people at least regarded one variety of a $\rho \tau \epsilon \mu \iota \sigma i \alpha$ as

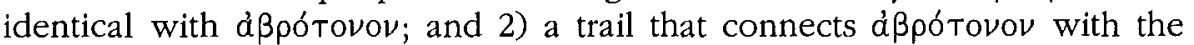

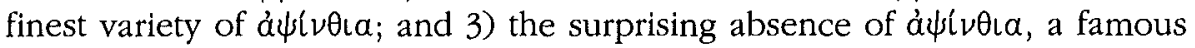
and powerful plant that is used in several religious settings and in medical writing in Egypt going back at least to $1500 \mathrm{BCE}$, from $P G M$ recipes. The word never appears there.

The problem of synonyms in ancient writing on plants is enormous. Authors provide synonyms to be helpful, being aware that certain plants are called by different names in different regions. But it often happens that a name given by them as a synonym for something else ("plant A"), is also a name under which they themselves or another author will discuss an entirely different plant ("plant B"). ${ }^{166}$ When this happens it is usually unclear whether or not the group or source text that uses the synonym for "plant $A$ " also uses the same word for "plant B" and if so, whether or not this group or source considers these to be actually the same plant, or simply two plants that are interchangeable in recipes, even if the botanical author presenting the synonym does not. In the case of the plant under discussion, both Pliny and Dioscorides note that a particular variety of $\alpha \rho \tau \epsilon \mu \iota \sigma \alpha$, to which neither author assigns a specific variety name, has a single stem, ${ }^{167}$ smells nice, is useful against poisons and "beasts," and flowers around grape ripening time, for which reason it is sometimes called "botrys;" both authors also note that some call it "ambrosia." For these two authors, botrys and ambrosia are different plants, and each has separate, further discussions of them. But, when discussing botrys, Pliny says that it is bushy, and therefore not the same as the single-stemmed plant discussed under "artemisia." He then adds that artemisia is a synonym for botrys, as is "ambrosia," a synonym in use among the Cappadocians. When Dioscorides discusses $\alpha \mu \beta \rho o \sigma i a$ he remarks

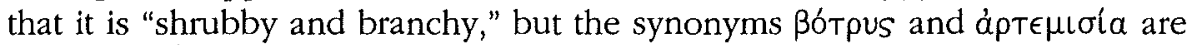
again noted; he concludes by noting that Cappadocians use the plant in wreaths.

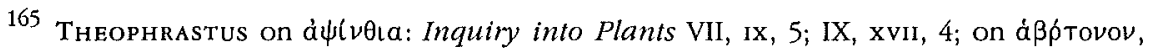
Inquiry VI, vII, 2-4. This reference to a $\beta \rho$ Tovov is discussed fully in the recent edition of Theophrastus by S. Amigues, Théopbraste : Recherches sur les Plantes, Tome III (Livres VVD, Paris, 1993, p. 197-199. This chapter is concerned chiefly with the propagation of the plant.

166 Or an animal or insect; see for example S. Amigues, "BOUPRHSTIS, Nom d'animal et nom de plante", RPb 64 (1990), p. 89-97.

167 In the Greek of Dioscorides here this is not a name but a description - $\dot{\alpha} \pi \lambda$ ov̂ $\nu \hat{\varphi}$

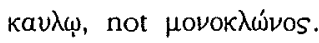




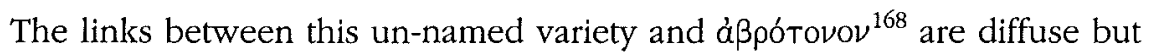
tantalizing. In the first place, the word aßpótovov may relate somehow to the adjective åßротós, which means roughly "not-of-man," e.g., "holy;" the more well known adjective $\alpha \mu \beta \rho \circ \tau o s$, to which the plant name $\alpha \mu \beta \rho o \sigma \alpha \alpha$ may in turn be related, means the same thing. The term aßßpotós for "holy" is not common, it appears only once, in Homer. ${ }^{169}$ I do not mean to suggest an etymological argument here, that the plants must be the same because of some ancient identity of terms. But I do think that the terms are sufficiently alike that general readers in the Roman period, who enjoyed etymological links of exactly this kind (especially Pliny), might have made an association between them and therefore discussed the terms as synonyms for the same plant. $^{170}$

The synonym-links between these two plants continue if we consider Pseudo-Dioscorides as well as Dioscorides himself. When one encounters a reference to "Pseudo-Dioscorides" either without the title of a work, or with the title $\pi \epsilon \rho i$ ü $\lambda$ S (Materia Medica), what is meant by this is a particular manuscript tradition of Dioscorides' main work itself. The earliest of many witnesses to this branch of the tradition is a fantastic illuminated manuscript prepared for presentation to Anicia Juliana, daughter of the emperor Flavius Anicius Olybrius, in around $512 \mathrm{CE} .{ }^{171}$ In this tradition, the plants discussed by Dioscorides have been totally rearranged and appear in alphabetical order; in addition, several lines are added to the description of each plant, listing other names by which it may be known. These lines are "PseudoDioscorides," mainly because in the earliest non-alphabetical witnesses to $\pi \epsilon \rho i$ U $\lambda \eta S$, they are not present. Although these additions and synonyms may not have value for reconstructing Dioscorides' great project, or for the pharmacological knowledge of the first century $\mathrm{CE}$, they are potentially of great importance for the study of $P G M$ materials, since they are so much closer to them in time, and may reflect current colloquial names that may also appear in $P G M$.

For Pseudo-Dioscorides, all varieties of $\dot{\alpha} \rho \tau \epsilon \mu \iota \mathrm{l} \alpha$ are synonymous with $\alpha \mu \beta \rho o \sigma i \alpha$, and, more importantly, this author discusses a discrete, named variety of the plant, the very $\dot{\alpha} \rho \tau \epsilon \mu \iota \sigma l a \mu o \nu \circ \kappa \lambda \omega \nu o s$ that appears so often in $P G M{ }^{172}$ The text then gives a long list of synonyms, many of which relate to

${ }^{168}$ LSJ lists the word with both breathings as possible. When Pliny gives the word in Latin, it is habrotanum.

169 Iliad XIV, 78.

170 For a study of the influence of botanical writing on the poetry of Theocritus, see S. Amigues, "De la botanique à la poésie dans les Idylles de Théocrite", REG 109 (1996), p. $467-488$.

171 Vind.med.gr. 1; excellent discussion of full manuscript tradition in RIDDLE, Dioscorides (cit. n. 91), p. 181-217. Riddle gives the name as "Clavius;" I am grateful to Marie-Hélène Marganne for the correction.

${ }^{172}$ Discussion and references in ANDrÉ, Les noms de plantes (cit. n. 154), p. 26. 


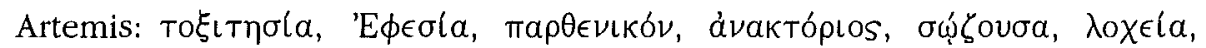

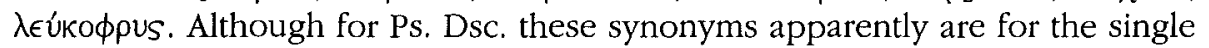
stemmed variety only, Pliny notes that the artemisias overall are either named in honor of Artemisia, the wife of Mausolus, the plant having previously been called partbenis, or are named after Artemis (Eilythuia) herself, since the plant is good for "the troubles of women." 173 For Ps. Dsc. the single-stemmed variety appears to be the more important of the two, but the text does note that a second, multi-branched variety is called "by some"

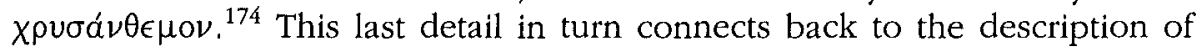
aßßótovov in Dioscorides and Pliny, both of whom mention its goldencolored flowers.

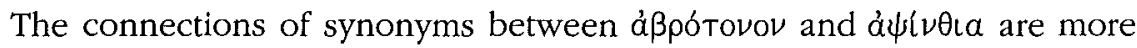
direct. Ps. Dsc. clearly states that "Romans" call the plant $\dot{\alpha} \psi i \nu \theta$ เou $\mu$

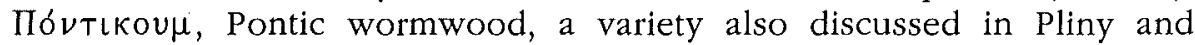
Dioscorides, for whom the Pontic is the finest di $\psi^{\prime} \nu \theta_{\iota} \alpha$ available. So at the end of this tour of synonyms, we see that there is a weak possibility that in the time of Ps. Dsc., there might have been among some groups an idea that

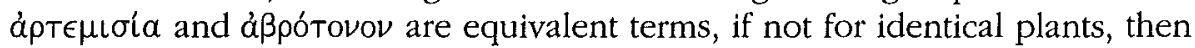
at least for use in medicines and recipes (through the medium of the term á $\mu \beta \rho \sigma^{\prime}(a)$. Further, it is clear that in his time at least some "Romans" believed that aßpótovov was either the same substance as Pontic wormwood, ${ }^{175}$ or was interchangeable with it in recipes, which is really the more important

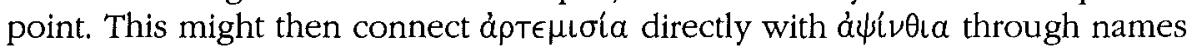
and language, reinforcing a connection that already exists in the uses of the plants (among other things, for diseases of women), and their characteristic bitterness.

The reason for going into all of this in such excruciating detail is because of the strange absence of $\dot{\alpha} \psi l \nu \theta \iota \alpha$, in any of its several varieties, from $P G M$ recipes; this would be easily explained if $P G M$ texts simply use a different word for the plant. Both Pliny and Dioscorides initiate their discussions of á $\psi i v \theta$ ia by noting how famous it is, and each reports several uses of the plant that would make it ideal for $P G M$ recipes, for both religious and practical reasons. Pliny remarks that the plant is used in Roman religion, in a ritual

${ }^{173} N H \mathrm{XXV}, \mathrm{xxxvI}, 73$. Several plants are named through analogies between various mythic or famous figures, and some aspect of their uses; a careful study of the plant

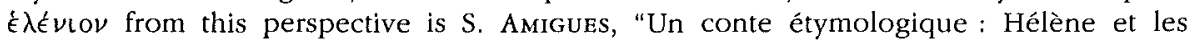
Serpents", JS (juillet-décembre 1990), p. 177-98.

174 Materia Medica III, 113.

175 The identification between these two plants is also accepted by ANDré, Les noms de plantes (cit. n. 154), p. 1 and p. 115. Here one variety of (h)abrotonum and the Pontic variety of absinthium are both Artemisia abrotonum L. 
chariot race on the Capitoline Hill, in which the victor is given it to drink. ${ }^{176}$ Also, both he and Dioscorides note that one variety, the $\theta a \lambda a$ or best at Taposiris in Egypt, ${ }^{177}$ and is used there by priests of Isis, who carry branches of it in processions. ${ }^{178}$ Elsewhere, both authorities note that it has antidote properties, that it repels gnats and keeps moths out of clothes, that it can induce sleep if placed under the pillow, and that mixed with ink, it prevents mice from eating up the writing. This last point is particularly

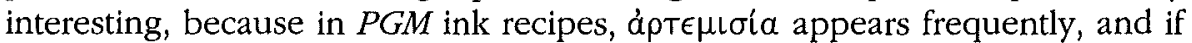
it were interchangeable with $\dot{\alpha} \psi(\nu \theta<\alpha$, this would be a practical, rather than symbolic, explanation for its presence there. The religious and/or medical importance of $d \psi\left(\nu \theta_{\iota} \alpha\right.$ is also suggested by the fact that the Pontic variety is included in Diocletian's Edict of 301, among the same list of "pigments" or perfumes in which the incenses appear. ${ }^{179}$ Unfortunately, the price of the plant is not preserved.

The use of $\dot{\alpha} \psi l \nu \theta \iota \alpha$ by a certain group of Isis priests is also of interest, especially for the second main question of this paper, the degree of Egyptian priestly practice or knowledge that is reflected in $P G M$ formularies. Absinthe was certainly a component of Egyptian medical knowledge, and it is attested under the hieroglyphic word $s^{c} m$ as early as the Ebers papyrus, ${ }^{180}$ and that the word and the plant continued to be important in Egypt is demonstrated by another Pseudo-Dioscoridean synonym, in which the text correctly notes, "Egyptians call it somi." However, this passage also states that "Romans" call the $\theta a \lambda a ́ \sigma \sigma \iota \nu \nu$ variety á $\psi \iota \nu \theta \iota o u \mu ~ \Sigma a \nu \tau o ́ v \iota k o u \mu$, Santonic wormwood, a variety specifically stated by Pliny and Dioscorides to come from the Santonii in Gaul. It seems so improbable that these could be confused, that it suggests that Ps. Dsc. includes in its synonym lists varieties that are interchangeable in recipes, or that are believed to be identical, despite coming from different localities.

However, this brings us no closer to a resolution of the problem of the relationship between $\dot{\alpha} \rho \tau \epsilon \mu \iota \tau / \alpha$ and $\dot{\alpha} \psi\langle\nu \theta \iota \alpha$, in any of their varieties. For conclusions there can only be a train of possibilities. If there is identity or

176 NH XXVII, xxvIII, 45. This, according to Pliny, confers the gift of "health," but the strong emetic and laxative powers of the plant in most varieties may have made the prize an ambiguous gift.

177 Probably Taposiris Magna, = Djedu; $45 \mathrm{~km} \mathrm{w}$ of Alexandria, at the tip of the Mareotic lake; K.A. BARD (ed.), Encyclopedia of the Archaeology of Ancient Egypt, London, 1999, p. 759-761.

178 NH XXVII, xxIx, 53; Materia Medica III, 23. See also MARganne, Les références à l'Égypte (cit. n. 164), p. 31.8-319.

179 Discussed above, p. 73-74. The Pontic wormwood itself appears at ch. 34, 1. 19 of the Edict; Gracchero, Edictum Diocletiani (cit. n. 80), p. 214-215; Crawford-Reynolds, l.c. (n. 81), p. 181, 205.

180 J.F. Nunn, Ancient Egyptian Medicine, Norman, OK, 1996, p. 152; 158-161; ManNiche, Egyptian Herbal (cit. n. 119), p. 80. 
interchangeability between them, then, the use of a $\rho \tau \epsilon \mu \iota \sigma i \alpha$ in $P G M$ recipes is another example of the use of substances from temple and domestic worship, in ways roughly analogous to their use in those settings: as part of the arrangement on an offering table, and, less frequently, burned upon an altar. ${ }^{181}$ For the first question of this study, the question of availability and expense, no real conclusion can be reached because of the wide range of places where the plant can grow, and also because the price of Pontic wormwood, a very high quality type, is unfortunately broken away from Diocletian's Edict. However, the fact that it does appear there at all, as an item in need of price control, may suggest that it was or could be expensive. For the second question, it is clear that a variety of $\alpha \psi i \nu \theta \imath \alpha$ did grow in Egypt and was employed there for both religious and medical purposes. If $\alpha \dot{\psi} \psi \mathrm{i} v \theta i \alpha$ and $\alpha \rho \tau \epsilon \mu \iota \sigma \alpha a$ are the same or interchangeable, then it would seem that an element of priestly practice at Taposiris, and perhaps elsewhere, ${ }^{182}$ is reflected in $P G M$. However, because the plant is a very common one that grows in so many other places, its presence in a recipe is not a firm indication of a source in specifically Egyptian temple practice.

If there is no identity or interchangeability between $\alpha \rho \tau \epsilon \mu \iota \sigma^{\prime} \alpha$ and $\dot{\alpha} \psi^{\prime}(\nu \theta \iota \alpha$, then we do not have a third category substance at all, but rather a fourth category one, a plant that is well-known as a minor medical plant but that is used in PGM in completely different ways. This is why I began by saying that this discussion either does or does not belong in the present study. I do not think that it is now possible to arrive at any firm conclusion about this problem. Our own perspectives can influence the choice that is made; if we see $P G M$ materials as transformed Egyptian priestly material, then it will be more attractive to see the a $\rho \tau \epsilon \mu \iota \sigma l \alpha$ as a plant known to be an important component of Egyptian medicine and priestly practice; however, the fact that the great Demotic Magical Papyrus does not seem to call for any form of artemisia, somi, absinthe, etc. remains then to be explained. If we see them as Egyptian examples of a pan-Mediterranean but basically Greek tradition, it is preferable not to see the terms as interchangeable but to look to Gaul,

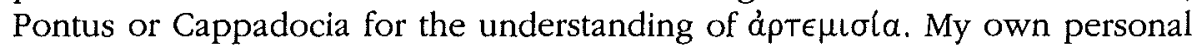

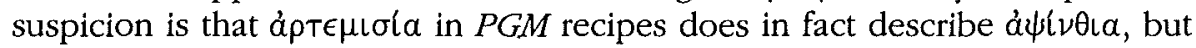
as the preceding pages show, there is no way to really demonstrate this in any useful way.

181 GaIllard-Seux, Le 'sang de basilic' (cit. n. 155) p. 232, argues that the singlestemmed wormwood is probably not common artemisia.

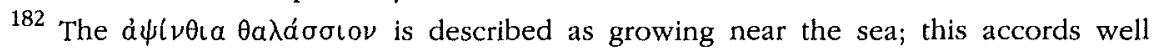
with the location of Taposiris for its use. 


\section{Conclusions}

This paper has been an attempt to carry forward the social history of $P G M$ texts, by focusing upon a selection of ingredients for which some economic information may be obtained. With regard to wormwood, no firm conclusions could be reached, due to the lexicographical problems and to the fact that it is a common plant that grows wild and in gardens throughout Europe, Asia Minor, and Egypt. Its use, though fascinating, cannot be used to indicate a particular social location, geographical region, or religious tradition.

In the cases of frankincense and myrrh, we see that 1) though imported and expensive, they were widely available in marketplaces throughout the Mediterranean world and were important components of many kinds of religious activity; 2) that where $P G M$ formularies specify a variety, it is usually the most valuable and expensive kind; and 3) therefore it is possible that the formularies assume a well-off practitioner with access to all sorts of imported goods; 4) this in turn may imply an urban rather than a rural setting; and 5) that though the incenses are important in Egyptian religion, they are neither native to nor diagnostic of an Egyptian setting. Similarly, with regard to pinecones, although no absolute or relative prices were uncovered, we see that 1) they are probably urban marketplace items at least in Egypt, and 2) the quantities usually required in $P G M$ formularies are analogous to that used in a funeral in a well-to-do family; and 3) pinecones are also not really native wild products of Egypt, and are used in religious rituals from many and diverse places.

These observations based upon recipe ingredients would tend to suggest that the world assumed by $P G M$ formularies is wealthy and urban. It should be noted, however, that the great majority of the spells discussed here, that use these high-end ingredients, are revelatory, and that in general the revelatory or divinatory spells tend to be the fanciest and longest in a given formulary, and to have the most complicated recipes. There are also some extremely long, elaborate, and expensive erotic spells that imply lots of money and lots of time, requiring many imported ingredients and several days to complete. In contrast to this, spells for health, healing, good business, and aversion of anger tend to be simple and inexpensive; and of course there are many simple and inexpensive erotic spells, and especially aphrodisiac lotions, that are easy to prepare from common ingredients. I think that in this disparity, we glimpse some of the varied and disparate sources ${ }^{183}$ from which

183 At least the Homer passages certainly suggest this - there is nothing diagnostically Egyptian about them. Chr. FAraone also argues that $P G M$ formularies derive from a broadly Mediterranean cultural background; Ancient Greek Love Magic (cit, n. 5), p. 34-38; "The Mystodokos and the Dark-Eyed Maidens: Multicultural Influences on a Late 
$P G M$ formularies in their present forms were compiled: visionary or meditative practices of the educated urban elite, with a small number of elaborate erotic binding and summoning spells thrown in for those times when a revelation from the gods just isn't enough; now side by side with, among many other things, simple spells for very practical results (good health, good business, good sex, avoidance of a superior's anger) that sometimes reflect a more rural setting, and very often reflect people of modest means without a great deal of spare time. That these elements exist now side by side with sophisticated visionary material in the great formularies - perhaps anthologies is a better term - may be due either to very haphazard collection techniques, or to the specific interests and capabilities of whoever compiled them. They do not necessarily imply a single locus of ritual power that would be accessed by both humble and elite persons desiring assistance, who would be met with rituals specifically designed for their educational levels, geographical locations, and bank accounts: the "magician-model." They might in fact suggest that there were rites and materials current at many different places and social levels, that have been combined - the combination being a literary rather than a specifically religious phenomenon. Therefore, the social background of PGM materials cannot be neatly and exclusively pigeon-holed, as either "urban, elite," or "rural, Egyptian." In combination with a text's citations, sacred names, length of ritual, and explanatory sections, consideration of recipe ingredients can help in the determination of who may have used a given ritual and why, but only if studied on a spell by spell basis, rather than by anthology.

Lynn R. LIDONNICI

Vassar College

Poughkeepsie, NY 12604

Hellenistic Charm", in M. Meyer, P. Mireckı (eds.), Ancient Magic and Ritual Power I, Leiden, 1996, p. 297-334, esp. 326-327. 